Germany and the United States. But if, instead of using Mr. Levinstein's figures, we take the annual exports per head of population, which is after all the truest test, we find that in the period $1870-74$ they were $7 l .7 s$. $3 d$. per head, but in 1895-99 they had fallen to $5 l$. 19s. $5 d$. In Germany during the same periods they were $2 l .16 s$. $7 d$. and $3 l .7 s .22 i$. respectively, while in the United States they rose from $2 l$. 9s. rId. to 2l. $18 s .4$. These figures show that although per head of population we export more than either of these nations, yet during the last forty years they have been increasing their exports per head, but those of the United Kingdom have been declining. The figures are much more striking if at the same time we examine the increase of population which has taken place in the three lands during the same period. From $187 \mathrm{I}$ to Igor, the population of the United Kingdom increased by 31.7 per cent., while that of Germany increased 373 per cent. and that of America 96.1 per cent. ${ }^{1}$

I will now take another comparison-the five years' averages of the annual exports at the beginning and end of the period 1880-1900. Here it will be seen that the increase of exports of the United Kingdom only amounted to 6.4 per cent. (234 to 249 millions), but that Germany showed an increase of $23^{\circ} 1$ per cent. ( 156 to 192 millions) and the United States 42.8 per cent. (166 to 237 millions).

Again, we are unable to show such large increases in the quantity of pig iron produced as are Germany and America. In the years $1870-74$, the United Kingdom was far and away ahead of all other nations, producing 6.4 million tons against I 8 million tons by Germany and $2 \cdot 2$ million tons by America. But in $1896-1900$, the amounts were for the United Kingdom 8.9, Germany $7 \% 4$, and Aınerica $11 \cdot 5$ million tons.

Mr. Evershed objects to Mr. Levinstein taking a "fat year" as the starting point for his statistics, but, as I have already pointed out, the years 1899 and 1900, which come within Mr. Levinstein's decade, were also exceptionally good years and thus help to bring up the average. But I think that although Mr. Evershed lias taken exception to the use of the year 1890 , he will agree with all scientific and broad-minded men in being glad that a man of Mr. Levinstein's experience should have the courage to speak out and try to wake the nation up to a sense of its responsibilities.

F. Mollwo Pfrkin.

\section{Bipedal Locomotion of Lizards.}

I KEYT for many years in a glass case some specimens of Lacerta viridis, and often observed them after a feed playing in the sunlight in a peculiar manner, first drinking water, which they lapped up with their wide forked tongues. The play was a sort of dance. The lizard stands on his hindlegs and, raising the fore part of his body, executes a rapid, playful waving of the forelegs. When both forelegs are used, they move in unison; sometimes, however, only one is employed. This action seemed to be meant as an attraction, the motions being performed facing another lizard, who often responded with answering waves of the forelegs; at times during the pastime, the pair would lick each other. I observed the females indulyed oftenest in this coquettish dance, though the males would go through the same performance, strange to say, as often with each other as with a female for a partner to set to.

One female I kept for five years always, when excited, tork a perpendicular position, progressing on her hindlegs with the fore part of the body lifted, and would play, running at my hand and biting, always in that erect pose.

The blue lizards of Capri, which I have kept for years in confinement, move along upright under excitement, also using bipedal action.

September 23.

\section{RUDOLPH LUDWIG KARL VIRCHOW.}

"All that lives must die,

Passing through nature to eternity."

THE great master and founder of modern pathology, Rudolph Virchow, has passed away, full of years and full of honours, mourned, not only by his fellow countrymen, but by the whole scientific world. A fall early in January last resulting in a fractured thigh was the ultimate cause of his death, which occurred on September 5 .

1 In Germany and America, the census returns are for 1900 .

NO. I 718 , VOL. 66$]$
Born at Schilvelbein in Pomerania in 1821 , Virchow attended the public school of his native town until his thirteenth year, when he entered the gymnasium of Cöslin and early distinguished himself by his linguistic attainments. In 1839, he entered the Friedrich.Wilhelm Institut, a training college for army medical officers, having among his teachers Müller and Caspar and among his fellow students Helmholtz, and in 1843 proceeded to take his degree. He had already shown such promise that he was released from service with the army and was attached to the Charite Hospital as prosector of anatomy, acting as assistant to Froriep, whom he succeeded in 1846. About this time he founded, in collaboration with Reinhardt, the famous Archiv, and after the death of the latter continued to edit it himself. In 1848 , he carried out an investigation into an epidemic of relapsing fever in Silesia, and so uncompromising were his strictures on the authorities, together with his alliance to the ultra-Radical party, that he was compelled to resign his appointment at the Charite. Already, however, his reputation as a pathologist was made, and he was immediately offered and accepted the chair of pathology at Wurzburg, where for the next seven years he devoted himself to pathological research. In 1856 , on the death of Hemsbach, the Faculty of the University of Berlin petitioned for his recall, and, in spite of bitter opposition, was successful in its application, and Virchow returned to his old University for the remainder of his life, founding the Pathological Institute and the Museum of Morbid Anatomy.

Virchow's life was a strenuous one, and being blessed with a wonderful constitution he was able to devote himself to, and to become a master in, many pursuits, any one of which is usually sufficient to fill the life of ordinary mortals. In addition to his pathological chair, the duties of which he fulfilled up to the time of his accident, he was ethnologist and anthropologist, arch:æologist and Egyptologist, politician, a member of the Berlin Municipal Council for forty years, a member of the Prussian Chamber from 1862 to 1878 , where he was the recognised leader of the Radical party and for fifteen years chairman of the Finance Committee. In 1880 , he was elected a member of the Imperial Reichstag, but took little active part in its debates. One of his most important public works was concerned with the introduction of a system of drainage and with the installation of sewage farms, whereby Berlin has become one of the healthiest cities of Europe.

Of the man it may be said that he was beloved by his family and by his intimates. Short of stature and spare of figure, with grizzled hair and piercing grey eyes covered with spectacles, his was not a striking personality. Nor was he an orator, having a somewhat thin and weak voice and impassive delivery, but what he said was always to the point and clothed in simple but logical language, and he compelled a hearing by his very earnestness and simplicity. His political views and his uncompromising manner of stating them unquestionably prevented a full measure of State recognition of his genius.

As a teacher he attracted students from all parts of the world. Until his time, autopsies had been performed in a very perfunctory manner, the supposed seat of disease alone being examined. Virchow, however, submitted all the organs and tissues to a careful scrutiny, thereby in course of time as data accumulated proving the interdependence of one condition upon another and showing how widespread might be the effects of a limited lesion. At his demonstrations, the specimens were subjected to a rapid description and criticism, rough sections were cut and placed under the microscope, which was mounted upon a trolley running on rails, and so could be submitted without disturbance to the scrutiny of each member of the class. Drawings of the specimens 